\title{
PENERAPAN METODE TEAMS GAMES TOURNAMENT (TGT) UNTUK MENINGKATKAN KECERDASAN EMOSIONAL ANAK PADA SISWA KELAS V SD MUHAMMADIYAH AMBARKETAWANG 2
}

\author{
Usi Usmarani $^{1}$, Muhammad Ragil Kurniawan ${ }^{2}$ \\ PGSD FKIP Universitas Ahmad Dahlan \\ usimawanda@gmail.com
}

\begin{abstract}
Many students experience emotional intelligence problems. This is seen in students who prefer to disturb their friends during the learning process, are angry with the teacher when given advice. Many also cannot regulate their moods like often shouting in class, so they cannot control their emotions when they are angry and upset both at their friends and their teachers. The application of the Teams Games Tournament (TGT) is expected to increase children's emotional intelligence, therefore this study aims to determine the increase in emotional intelligence using the application of the Teams Games Tournament (TGT) in fifth grade students of SD Muhammadiyah Ambarketawang 2.

This research was included in a class action research consisting of two cycles. The subject of this study was fifth grade students of Muhammadiyah Ambarketawang Elementary School 2. The object of this research was SD Muhammadiyah Ambarketawang 2. This data collection technique was in the form of observation, questionnaires, and documentation. Data analysis used qualitative and quantitative analysis.

The results showed that there was an increase in children's emotional intelligence using the Teams Games Tournament (TGT) method. Increased emotional intelligence can be seen from the acquisition of the pretest percentage score of $43.75 \%$, after the action results of the percentage score of the first cycle to $68.75 \%$, while the results of the percentage cycle II score to $81.25 \%$ included in the excellent category. Students can understand and be able to manage emotions well, there is mutual respect between friends, there is an increase in motivation in students, and students can establish good relations with others. The results of this study indicate that emotional intelligence can be improved through the Teams Games Tournament (TGT) method.
\end{abstract}

Keywords: Children's emotional intelligence, Teams Games Tournament (TGT)

\begin{abstract}
ABSTRAK
Banyak siswa yang mengalami masalah kecerdasan emosional. Hal ini terlihat pada siswa yang lebih suka mengganggu temannya saat proses belajar, suka marah kepada guru saat diberi nasihat. Banyak juga yang tidak dapat mengatur suasana hatinya seperti sering berteriak-teriak didalam kelas, sehingga tidak dapat mengontrol emosi saat marah serta kesal baik pada temannya maupun pada gurunya. Penerapan Teams Games Tournament (TGT) diharapkan dapat meningkatkan kecerdasan emosional anak oleh karena itu penelitian ini bertujuan untuk mengetahui peningkatan kecerdasan emosional menggunakan penerapan Teams Games Tournament (TGT) pada siswa kelas V SD Muhammadiyah Ambarketawang 2.
\end{abstract}


Penelitian ini termasuk dalam penelitian tindakan kelas yang terdiri atas dua siklus. Subjek penelitian ini adalah siswa kelas V SD Muhammadiyah Ambarketawang 2. Objek penelitian ini adalah SD Muhammadiyah Ambarketawang 2. Teknik pengumpulan data ini berupa observasi, angket, dan dokumentasi. Analisis data menggunakan analisis kualitatif dan kuantitatif..

Hasil penelitian menunjukkan bahwa adanya peningkatan kecerdasan emosional anak dengan menggunakan metode Teams Games Tournamet (TGT). Peningkatan kecerdasan emosional dapat dilihat dari perolehan hasil skor presentase pretest sebesar $43,75 \%$, setelah dilakukan tindakan hasil skor presentase siklus I menjadi $68,75 \%$, sedangkan hasil skor presentase siklus II menjadi $81,25 \%$ termasuk dalam kategori sangat baik. Siswa sudah dapat memahami dan mampu mengelola emosi dengan baik, adanya rasa saling menghargai antar teman, adanya peningkatan motivasi pada siswa, dan siswa dapat menjalin hubungan baik dengan orang lain. Hasil peneitian ini menunjukkan bahwa kecerdasan emosional dapat ditingkatkan melalui metode Teams Games Tournament (TGT).

Kata kunci: Kecerdasan emosional anak, Teams Games Tournament (TGT)

\section{PENDAHULUAN}

Orang tua pada umumnya beranggapan bahwa anak yang cerdas adalah anak yang memiliki skor tes IQ tinggi. Namun kenyataannya angka IQ yang tinggi berdasarkan hasil tes yang diikuti anak-anak bukanlah jaminan kesuksesan anak di masa depan kelak. Ada faktor lain yang tidak kalah penting, yaitu kecerdasan emosional. Penelitian-penelitian terakhir mengungkapkan bahwa kini kita berusaha keras membuat anak kita lebih cerdas, atau paling tidak menghasilkan nilai lebih baik dalam uji-uji IQ standar. Namun ironisnya, sementara dari generasi ke generasi anak-anak makin cerdas, keterampilan emosional dan sosialnya merosot tajam. Banyak pakar ilmu sosial percaya bahwa masalah anak dewasa ini dapat dirunut ke peliknya perubahan-perubahan pola sosial yang telah terjadi dalam empat puluh tahun terakhir, termasuk meningkatnya angka perceraian, meresapnya pengaruh negatif TV dan media, kurangnya rasa hormat kepada sekolah sebagai sumber otoritas, dan semakin sedikitnya waktu yang disediakan oleh orangtua untuk anak-anak mereka (Lawrence, 2003:10-12).

Menurut Mitch Anthony dalam (Alfasnur, 2013: 17) kecerdasan emosional adalah masalah mengenali diri anda sendiri, mengenali orang-orang yang ada di sekeliling anda, dan mengenali penyesuaian yang perlu anda laukan. Sedangkan, menurut Lawrence (2003: 4) kecerdasan emosional atau EQ, bukan didasarkan pada kepintaran seorang anak, melainkan pada sesuatu yang dahulu disebut karakteristik pribadi atau "karakter". Penelitian-penelitian sekarang menemukan bahwa keterampilan sosial dan emosional ini mungkin dan bahkan lebih penting bagi keberhasilan hidup ketimbang kemampuan intelegensi. Dengan kata lain, memilki EQ tinggi mungkin lebih penting dalam pencapaian keberhasilan ketimbang IQ tinggi yang diukur berdasarkan uji standar terhadap kecerdasan kognitif verbal dan nonverbal.

Menurut Goleman (2005: 44) IQ menyumbang kira-kira 20\% bagi faktor-faktor yang menentukan sukses dalam hidup, maka yang $80 \%$ diisi oleh kekuatan-kekuatan lain. Ungkapan Goleman ini seolah menjadi jawaban bagi situasi aneh yang sering terjadi di tengah masyarakat, dimana ada orang-orang yang diketahui ber-IQ tinggi ternyata tidak mampu mencapai prestasi yang lebih baik dari sesama yang ber-IQ lebih rendah. Mengingat pentingnya peranan kecerdasan emosional bagi kesuksesan suatu individu, maka pendidikan sebagai basis pengembangan Sumber Daya Alam harus mampu menerapkan metode atau model pembelajaran yang tepat dalam upaya peningkatan kecerdasan emosional siswa. Menurut Goleman (2005: 58) kecerdasan emosi (EQ) pada suatu individu dapat ditingkatkan dengan mengembangan 5 dimensi penting kecerdasan 
emosional yaitu: mengenal emosi diri, mengelola emosi, memotivasi diri sendiri, mengenali emosi orang lain (empati), dan kemampuan untuk membina hubungan dengan orang lain.

Berdasarkan pengamatan yang peneliti lakukan di SD Muhammadiyah Ambarketawang 2 pada saat magang, khususnya di kelas $\mathrm{V}$ para siswa mempunyai karakteristik yang berbeda-beda pada setiap anaknya, sangat terlihat banyak siswa yang mengalami masalah kecerdasan emosional. Hal ini terlihat pada siswa yang lebih suka mengganggu temannya saat proses belajar, tidak mau mendengarkan guru disaat belajar dan asyik dengan sendirinya, suka marah kepada guru saat diberi nasihat kalau anak tersebut punya salah, sering keluar kelas pada saat proses belajar, dan susah diatur saat guru menyuruh untuk kerja kelompok. Mereka juga banyak yang tidak dapat mengatur suasana hatinya seperti sering berteriak-teriak didalam kelas, sehingga tidak dapat mengontrol emosi saat marah serta kesal baik pada temen-temannya maupun pada guru. Ditemukan juga siswa yang tidak dapat bekerja sama dengan teman dan tidak dapat berempati kepada orang lain, dan saling memojokkan satu sama lainnya.

Dalam proses pembelajaran di sekolah, siswa selalu di tuntut untuk melakukan penyesuaian, karena belum tentu perlakuan mereka sesuai dengan apa yang diharapkan. Dalam hal ini kecerdasan emosional merupakan salah satu bagian dalam kegiatan belajar. Melalui kecerdasan emosional siswa dapat mengendalikan dirinya, dapat mengontrol perbuatan dan mengendalikan emosi, serta mampu menyelesaikan tugas dengan baik didorong dengan ketekunan untuk belajar. Apabila siswa yang bersangkutan tidak memiliki kecerdasan emosional maka siswa tersebut tidak dapat mengontrol perbuatannya, tidak dapat mengendalikan emosi serta tidak bisa menjalin hubungan baik dengan orang lain. Secara tidak langsung hal ini akan berpengaruh pada prestasi akademiknya (Alfasnur, 2013: 2)

Sebagai seorang guru, pastinya menginginkan para siswa untuk mematuhi aturan dan dapat mengikuti proses belajar dengan baik tanpa perlu ada bantahan, pertengkaran, maupun teriakan dari seorang guru. Dan untuk mengatasi masalah kecerdasan emosional siswa yang rendah, maka diperlukan suatu teknik sebagai upaya meningkatkan kecerdasan emosioanl sehingga siswa sadar berkeinginan untuk menata dirinya menjadi lebih baik lagi. Untuk mengatasi hal tersebut harus ada sebuah metode pembelajaran yang cocok untuk diterapkan kepada siswa yang mempunyai keragaman perilaku agar siswa dapat mengikuti proses pembelajaran di kelas dengan menyenangkan dan tidak merasa bosan saat proses pembelajaran berlangsung. Dalam memilih metode pembelajaran, guru harus memperhatikan keadaan atau kondisi siswa, bahan pelajaran serta sumber-sumber belajar yang ada agar penggunaan metode pembelajaran dapat berjalan secara efektif.

Guru dapat memilih metode Team Games Tournament (TGT) untuk diterapkan dalam proses pembelajaran di kelas V SD Muhammadiyah Ambarketawang 2 sebagai penguat materi dan melatih siswa dalam mengaktifkan kecerdasan emosional yang ada pada diri mereka. Karena pada usia mereka ini anak sudah mempunyai kemampuan membaca dan menulis dengan baik, dan pada siswa kelas V SD biasanya tingkat kesulitan materi pembelajaran mulai meningkat. Pada tingkat ini pula aspek sosial anak mulai tumbuh dan dapat melatih anak untuk mampu mengetahui keadaan emosi dirinya sendiri maupun keadaan emosi teman-temannya.

Menurut Huda (2013: 197) Teams Games Tournament (TGT) merupakan salah satu strategi pembelajaran kooperatif yang dikembangkan oleh Slavin (1995) untuk membantu siswa mereview dan menguasai materi pelajaran. Slavin menemukan bahwa TGT berhasil meningkatkan skill-skill dasar, pencapaian, interaksi positif antarsiswa, harga diri, dan sikap penerimaan pada siswa-siswa lain yang berbeda. Dalam TGT, siswa mempelajari 
materi di ruang kelas. Setiap siswa ditempatkan dalam satu kelompok yaitu terdiri dari 3 orang atau lebih dengan berkemampuan rendah, sedang, dan tinggi. Komposisi ini dicatat dalam tabel khusus (tabel turnamen), yaitu setiap minggunya harus diubah. Dalam TGT setiap anggota ditugaskan untuk mempelajari materi terlebih dahulu bersama anggotaanggotanya, barulah mereka diuji secara individual melalui game akademik.

Pembelajaran tipe TGT lebih diutamakan pada belajar kelompok siswa dan turnamen akademik. Dalam belajar kelompok siswa dituntut bekerja sama dan saling tolong menolong dalam menyelesaikan bahan pelajaran tertentu, sedangkan dalam turnamen siswa diberi kesempatan untuk bersaing atau berkompetisi dalam upaya meningkatkan daya saing atau aktivitas belajar siswa. Dengan adanya daya saing yang tinggi, akan lebih memotivasi siswa untuk lebih aktif, berani menghadapi tantangan, tenang menghadapi tantangan sehingga tidak depresi. Dalam pembelajaran kooperatif tipe TGT menungkinkan dapat meningkatkan aspek kognitif dan afektif siswa, sehingga dapat meningkatkan pengembangan kelima dimensi kecerdasan emosional sehingga nantinya dapat memberikan peningkatan terhadap kecerdasan emosional para siswa.

Berdasarkan hal-hal tersebut, inilah yang melatar belakangi penulis dalam melakukan penelitian seberapa efektif metode Teams Games Tournament (TGT) dalam meningkatkan kecerdasan emosional anak pada siswa kelas V di SD Muhammadiyah Ambarketawang 2, sebagaimana judul yang diangkat oleh peneliti adalah "Penerapan Metode Teams Games Tournament (TGT) dalam Meningkatkan Kecerdasan Emosional Anak Pada Siswa Kelas V di SD Muhammadiyah Ambarketawang 2."

\section{METODE PENELITIAN}

Jenis penelitian yang dilakukan dalam penelitian ini adalah penelitian tindakan kelas. Penelitian tindakan kelas ini merupakan suatu penelitian yang masalahnya muncul di dalam kelas dan dirasakan langsung oleh guru yang mengampu kelas tersebut. Penelitian ini menggunakan model kolaboratif, dimana peneliti melaksanakan penelitian tindakan kelas (PTK) yang memiliki rancangan tersendiri, tetapi dalam program pelaksanaanya, peneliti bekerjasama dengan guru kelas untuk memecahkan masalah yang ada di kelas ketika proses belajar mengajar berlangsung. Rancangan penelitian digunakan dengan dua siklus sebagaimana melakukan siklus 1, dapat terlihat letak keberhasilan ataupun hambatan dari pelaksanaan, kemudian peneliti bersama guru merancang atau menentukan kembali siklus 2. Waktu penelitian dilaksanakan pada bulan November 2017. Subjek penelitian adalah siswa kelas V SD Muhammadiyah Ambarketawang 2. Sedangkan yang menjadi objek dalam penelitian ini adalah SD Muhammadiyah Ambarketawang 2. Teknik pengumpulan data data menggunakan observasi, angket, dan dokumentasi. Observasi yang dilakukan adalah observasi pengamatan dalam TGT, Angket digunakan untuk mengumpulkan data siswa tentang tingkat kecerdasan emosional anak. Dokumentasi diperoleh dari foto, dan berkas-berkas yang terkait dengan kecerdasan emosional anak.

Teknik Analisis data dalam penelitian ini menggunakan analisis secara kualitatif dan kuantitatif. Analisis data kualitatif menggunakan model Miles dan Huberman yaitu reduksi penyajian data dan penarikan kesimpulan. Analisis data ini dilakukan untuk mengolah data yang diperoleh dari hasil observasi penelitian. Analisis data kuantitatif dilakukan dengan menggunakan rumus rata-rata statistik desktiptif. Rumus rata-rata digunakan untuk mengolah data yang diperoleh dari hasil angket kecerdasan emosional anak. Data ini digunakan untuk mengamati kecerdasan emosional anak yaitu dengan siswa mengisi lembar angket. Data hasil angket dapat dihitung menggunakan rumus. 


\section{HASIL DAN PEMBAHASAN}

Penelitian ini dilakukan dengan 2 siklus, masing-masing siklus dilakukan 2 kali pertemuan. Secara keseluruhan, tindakan yang dilakukan berjalan lancar. Pada siklus I kegiatan TGT berjalan dengan lancar tetapi ada beberapa siswa yang belum antusias dan konsentrasi dalam mengikuti kegiatan TGT. Terdapat siswa yang masih keluar masuk kelas saat pembelajaran berlangsung, dengan begitu siswa belum menyadari tentang kecerdasan emosional merupakan hal yang ingin ditingkatkan dalam diri siswa. Namun pada siswa yang lain sudah melakukan kegiatan dengan antusias dan serius, siswa lebih dapat memotivasi dirinya. Dilanjutkan pada siklus II, diadakan TGT kepada para siswa karena menurut peneliti masih ada beberapa siswa yang belum bisa melakukan TGT dengan baik. Dengan begitu peneliti berharap siswa dapat lebih berkonsentrasi lebih serta termotivasi dapat meningkatkan antusias yang tinggi dalam melakukan TGT. Sehingga dalam siklus II siswa dapat melakukan TGT dengan lebih baik lagi dari siklus pertama. Sehingga siswa dapat mengeluarkan emosi-emosi yang ada dalam diri mereka masingmasing ketika melakukan TGT agar mereka dapat termotivasi menjadi yang lebih baik dengan teman sekelompoknya.

Dilihat dari hasil observasi tindakan berlangsung menunjukkan adanya peningkatan pada aspek kecerdasan emosional yaitu kemampuan mengenal emosi diri, motivasi, keterampilan sosial, berempati dan pengendalian diri, sehingga yang terlihat siswa sudah tidak berteriak-teriak lagi ketika marah. Ketika sedih sering menyendiri sekarang sudah mampu menghadapi dengan bercerita kepada teman yang dipercaya atau kepada guru kelas. Ada peningkatan motivasi dalam belajar dan mengungkapkan pendapat. Pada peningkatan hasil pratindakan kecerdasan emosional dapat dilihat bagaimana nilai persentase siswa yang menunjukkan kecerdasan emosional mereka masih rendah.

Gambar 1. Hasil Pre test Subyek Penelitian

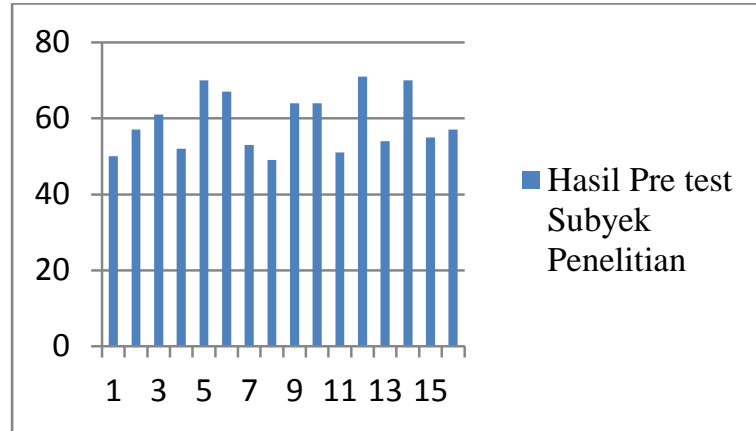

Nilai yang dapat dilihat diatas menunjukkan siswa memiliki skor persentase sebesar $43,75 \%$ itu menunjukkan bahwa kecerdasan emosional siswa masih sangat rendah. Sedangkan, pada, peningkatan hasil angket siklus pertama menunjukkan bahwa adanya peningkatan yang cukup signifikan pada skor persentase siswa.

Gambar 2. Hasil Angket Kecerdasan Emosional Siklus I

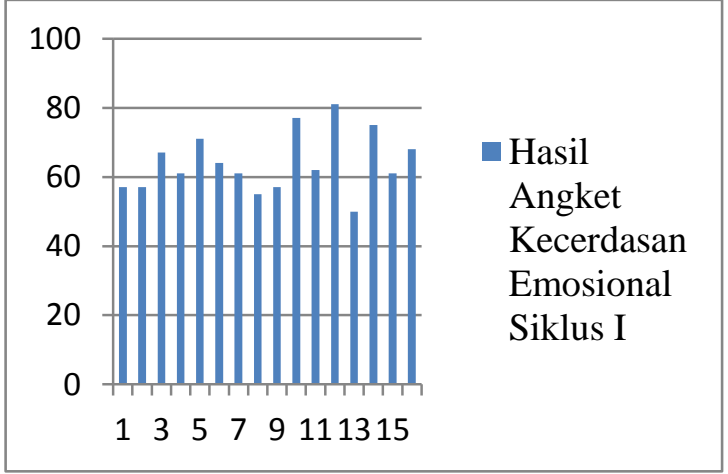


Nilai pratindakan semula 43,75\% menjadi $68,75 \%$. Pada hasil siklus pertama masih belum memenuhi indikator keberhasilan yang diinginkan oleh peneliti sehingga dilanjutkan pada siklus kedua.Pada siklus kedua mengalami peningkatan.

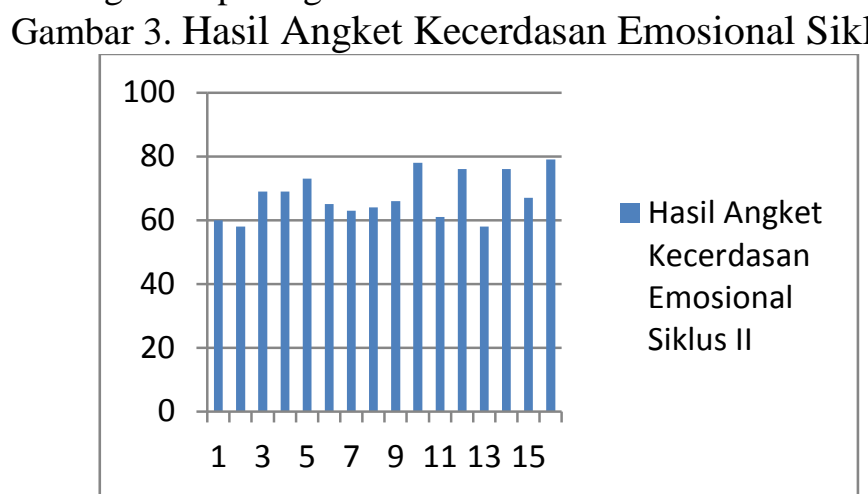

Hasil siklus pertama mendapat skor persentase sebesar $68,75 \%$ meningkat menjadi $81,25 \%$. Hasil tersebut menunjukkan bahwa peningkatan kecerdasan emosional siswa selalu meningkat tiap siklus. Hasil dari angket tersebut dikuatkan dengan hasil oservasi yang menunjukkan peningkatan kecerdasan emosional para siswa. Hasil observasi yang didapat, bahwa siswa dari tiap siklus menunjukkan adanya peningkatan secara keseluruhan pada kecerdasan emosional, misalnya siswa lebih termotivasi dalam belajar, siswa saling menghargai sesama teman maupun guru, siswa sudah tidak sering berteriak lagi didalam kelas, siswa tidak berkeliaran di depan kelas, dan ada motivasi yang timbul dalam diri siswa dalam belajar.

Hal diatas juga didukung oleh pendapat Peter Salovey dan Jack Mayer dalam Steven dan (Howard, 2002) "kecerdasan emosional adalah kemampuan untuk mengenali perasaan, meraih dan membangkitkan perasan untuk membantu pikiran, memahami perasaan dan maknanya, dan mengendalikan perasaan secara mendalam sehingga membantu perkembangan emosi dan intelektual. Selain itu siswa lebih mengenal emosi orang lain atau berempati. Contohnya ketika sedang berdiskusi bersama kelompok, kemampuan siswa dalam mengenal emosi orang lain juga mengalami peningkatan. Salah satu siswa yang tadinya kurang bergaul dengan teman yang lain sekarang mulai menunjukkan kedekatan dengan temannya dan sudah mulai mau membaur dengan teman-temanya.

Kegiatan ini dilakukan dengan TGT hal ini bertujuan untuk meningkatkan kecerdasan emosional siswa. Dalam TGT siswa terdapat aspek-aspek kecerdasan emosional anak yaitu kesadaran diri, motivasi, empati, keterampilan sosial, dan menjalin hubungan baik dengan orang lain, hal ini sangat membantu mengungkapkan emosi para siswa. Dalam kegiatan TGT juga membantu siswa untuk melatih siswa agar lebih percaya diri, tidak takut untuk mengungkapkan pendapat kepada orang lain serta tidak memilah milih antar teman. Pernyataan diatas juga didukung oleh Huda (2016) TGT merupakan salah strategi pembelajaran kooperatif yang dikembangkan oleh Slavin (1995) untuk membantu siswa mereview dan menguasai materi pelajaran, Slavin menemukan bahwa TGT berhasil meningkatkan skill-skill dasar, pencapaian, interaksi positif antar siswa, harga diri, dan sikap penerimaan pada siswa-siswa lain yang berbeda.

Berdasarkan pernyataan diatas bahwa TGT dapat membantu menyelesaikan masalah yang dihadapi, mengurangi ketegangan, dan dapat membantu meningkatkan kecerdasan emosional karena didalam metode TGT bertujuan untuk membantu siswa mengatasi masalah pribadi siswa maupun dengan orang lain dengan cara bermain bersama teman. Dari seluruh rangkaian kegiatan tindakan yang dilakukan berdasarkan teori yang ada berjalan lancar dan hasilnya sesuai dengan harapan yang diinginkan. Bahwa dapat disimpulkan secara umum keseluruhan tindakan yang diberikan berhasil karena dapat meningkatkan kecerdasan emosional anak.

\section{SIMPULAN}

Berdasarkan penelitian dan pembahasan yang telah di jabarkan pada bab IV, maka dapat disimpulkan bahwa metode Teams Games Tournament (TGT) dapat meningkatkan kecerdasan emosional anak pada siswa kelas V SD Muhammadiyah Ambarketawang 2, hal ini dapat dilihat 
dari hasil perbandingan antara hasil pre-test dengan hasil post-test yang mengalami peningkatan. Dengan kriteria keberhasilan yaitu apabila sebanyak minimal 75\% siswa mendapatkan nilai $\geq 61$ atau dengan presentase kecerdasan emosional dengan kriteria baik atau sangat baik. Hasil presentase kecerdasan emosional saat pre-test adalah 43,75\% atau sebanyak 7 siswa yang masuk ketegori baik, setelah dilakukan tindakan hasil post-test I menjadi 68,75\% atau sebanyak 11 siswa dengan kategori baik, dan hasil post-test II menjadi 81,25\% atau sebanyak 13 siswa dengan kategori sangat baik.

\section{DAFTAR PUSTAKA}

Alfasnur, Novi Okta. 2013. Upaya Meningkatkan Kecerdasan Emosional Melalui Metode Psikodrama Pada Siswa Kelas VIII SMP Negeri 1 Sleman Yogyakarta. Dalam skripsi, Fakultas Ilmu Pendidikan Universitas Negeri Yogyakarta.

Goleman, Daniel. 2001. Kecerdasan Emosional: Mengapa EI Lebih Penting daripada IQ. Jakarta: PT Gramedia Pustaka Utama.

Kecerdasan Emosional: Mengapa EI Lebih Penting daripada IQ. Jakarta: PT Gramedia Pustaka Utama. 2005. Kecerdasan Emosional: Mengapa EI Lebih Penting daripada IQ. Jakarta: PT Gramedia Pustaka Utama.

Huda, Miftahul. 2016. Model-Model Pengajaran dan Pembelajaran. Yogyakarta: Pustaka Pelajar.

Shapiro E. Lawrence. 2003. Mengajarkan Emotional Intelligence Pada Anak. Jakarta: PT Gramedia Pustaka Utama.

Slavin, E Robert. 2015. Cooperative Learning Teori, Riset dan Praktik. Bandung: Nusa Media.

Stein J. Steven dan Book E. Howard. 2002. Ledakan EQ: 15 Prinsip Dasar Kecerdasan Emosional Meraih Sukses. Bandung: Penerbit Kaifa.

Suharsimi, Arikunto. 2013. Prosedur Penelitian. Jakarta: Rineka Cipta.

Suharsimi, dkk. 2014. Penelitian Tindakan Kelas. Jakarta: PT Bumi Aksara. 